\title{
Floral Ontogeny and Sex Determination in Monoecious-type Persimmons
}

\author{
K. Y onemori, A. Sugiura, K. T anaka, and K . K ameda \\ Laboratory of Pomology, Faculty of A griculture, Kyoto U niversity, Sakyo-ku, Kyoto 606, Japan
}

Additional index words. Diospyros kaki, sexuality, flower differentiation

\begin{abstract}
Patterns of floral differentiation were studied in two monoecious-type Japanese persimmon (Diospyros kaki L.) cultivars Hana-gosho and Kakiyama-gaki. In both cultivars, the pistillate and staminate floral primordium started to differentiate in early June, and differentiation progressed until August, when the sepal primordia in pistillate flowers and petal primordia of staminate flowers had become evident. The buds then entered a quiescent, overwintering state. Thus, flower sex of monoecious-type persimmons was determined at a relatively early stage of floral development. Moreover, in both cultivars, sex differentiation was associated with previous history of the current season's shoots. Current season's shoots that bore pistillate flowers differentiated pistillate buds (mixed buds from which pistillate flowers emerge) at significantly higher rates than for shoots that bore staminate flowers. Similarly, shoots that bore staminate flowers produced staminate buds (mixed buds from which staminate flowers emerge) at a higher percentage than shoots that had borne pistillate flowers. With 'Hana-gosho', the flower type was also predictable with fair accuracy by bud position on the current season's shoot, i.e., pistillate flowers emerged from distal mixed buds, whereas staminate flowers arose predominantly from basal buds.
\end{abstract}

Flowers of the Japanese persimmon are borne laterally on current season's growth. The commercial cultivars exhibit three types of sex expression, those that: 1) bear only pistillate flowers (pistillate-type), 2) bear both pistillate and staminate flowers (monoecious-type), and 3) bear hermaphroditic flowers in addition to pistillate and staminate flowers (polygamomonoecioustype). Individuals bearing only staminate flowers might be present within the species but are not reported because they are of no economic value. Most commercial orchards are planted with pistillate-type cultivars and are interplanted with monoecioustypes as pollinizers.

Among monoecious-type cultivars, there is a cultivar-related difference in staminate flower formation, and some cultivars produce staminate flowers sporadically (Hume, 1913). The ratio of staminate to pistillate flowers produced varies by year even in the same tree (Kajiura and Blumenfeld, 1989). However, the factors affecting sex expression in trees are not clearly understood.

As with most other deciduous fruit trees, flower primordia of persimmons differentiate in the previous season within the terminal and lateral mixed buds of shoots (Sobajima, 1979). These buds overwinter in a quiescent state. A mixed bud has a preformed shoot with several nodes with flower primordia located in the axils of the leaf primordia. When the mixed bud emerges in spring, the preformed shoot elongates, bearing flowers that continue to develop until anthesis. In monoecious-types, a shoot bears either pistillate or staminate flowers, rarely both.

There is no information available on the floral ontogeny and course of differentiation of pistillate and staminate flowers of monoecious Japanese persimmon cultivars. In this report, we describe the course of differentiation of pistillate and staminate flowers and the possible basis of sex expression in this species.

Received for publication 3 Mar. 1992. Accepted for publication 12 Sept. 1992. This research was supported, in part, by grant-in-aid (no. 01480046) from the Ministry of Education, Science and Culture, Japan. We gratefully acknowledge the critical reading and suggestions about the manuscript done by K. Ryugo, Dept. of Pomology, Univ. of California, Davis. The cost of publishing this paper was defrayed in part by the payment of page charges. Under postal regulations, this paper therefore must be hereby marked advertisement solely to indicate this fact.

\section{Materials and Methods}

Mature trees of monoecious-types of Japanese persimmon ('Hana-gosho' and 'Kakiyama-gaki') growing at an experimental orchard of Kyoto Univ. were the source of buds. Preliminary scanning electron microscopic (SEM) observations were carried out in 1986 to classify the developmental stages of pistillate and staminate flowers. We collected buds on current shoots and stored them in 2 formalin : 1 acetic acid : 10 ethanol : 7 water from June to October. Buds were dissected, refixed in $1 \%$ osmic acid, dehydrated in ethanol, and critical-point dried using liquid $\mathrm{CO}_{2}$. The buds were observed with a JSM-T100 SEM (JEOL, Tokyo).

In 1990, a more detailed investigation was conducted to trace precisely the developmental process of pistillate and staminate flowers. Current season's growth, $\approx 30 \mathrm{~cm}$ long, was sampled from the two cultivars between 11 June and 1 Dec. at 10- to 40-day intervals. On each sampling date, five shoots that bore only pistillate flowers (pistillate shoots) and five shoots that bore only staminate flowers (staminate shoots) were collected from 'Hanagosho'; three shoots of each type were collected from 'Kakiyamagaki'. The terminal and three lower two, adjacent, lateral buds on each shoot were removed and stored separately in $2.5 \%$ glutaraldehyde containing $0.2 \%$ tannic acid. The time of appearance and the stage of development of the floral primordium in each bud were recorded as observed with a stereoscopic light microscope or SEM. The most advanced stages of the pistillate or staminate floral primordia in each bud were noted for each sampling date. For the SEM analysis, similar procedures were used as described by Yonemori and Matsushima (1987), except that specimens were coated with gold-palladium and scanned with a ALPHA-10 SEM (Akashi Manufacturer Co., Tokyo).

The involvement of the current season's shoot flower type and bud position in sex differentiation of the mixed buds were. also examined with both cultivars. The percentage of pistillate buds (mixed buds in which pistillate flowers differentiate) or staminate buds (mixed buds in which staminate flowers differentiate) relative to total dissected buds was calculated at each sampling date for terminal (1st) to 4th buds on each type of shoot. Five and three buds in each position of pistillate or staminate shoots of 'Hana-gosho' and 'Kakiyama-gaki' were dissected, respectively, starting after 
each bud first showed morphological signs of floral differentiation. The percentage based on each sample date was regarded as a replication.

\section{Results}

\section{Mode of floral differentiation}

In persimmons, a solitary, large, pistillate flower is usually borne in a leaf axil, whereas one or more small, staminate flowers are borne on a cyme (Fig. 1). Thus, the sex of a flower can be distinguished by the absence or presence of lateral flower primordia at an early stage of bud development.

According to the SEM photomicrographs, the mode of flower initiation and development are similar in the two cultivars. In June, an undifferentiated apex was formed at an axil of a leaf primordium within a mixed bud (Fig. 2). The subsequent development of both flower types was classified into five stages according to floral morphology (Fig. 3). The first sign of flower initiation was the flattening of this apex, forming a dome. An apex destined to become pistillate formed only one floral dome (Fig. 3a) upon which the sepal and petal primordia were differentiated acropetally (Fig. 3b-e). A small lateral apex often appeared at the base of the developing pistillate flower bud that remained undifferentiated (Fig. $3 \mathrm{~d}$ and e).

In the case of a staminate flower, the terminal apex flattened and began to initiate sepal primordia when the second and third lateral floral apices appeared, thus forming a cymose structure (Fig. 3fh). Concurrent with the appearance of four petal primordia on the terminal floral apex, four sepal primordia appeared on the smaller lateral flower primordia (Fig.3 $\mathrm{i}$ and j).

When the 40 'Hana-gosho' and 24 'Kakiyama-gaki' buds that were collected on selected dates were classified into five developmental stages based on microscopic and SEM analyses (Fig. 3), the distribution of the pistillate and staminate buds was established. The distribution patterns reveal that pistillate and staminate flower initiation in 'Hana-gosho' had already begun by 11 June (Fig.4). Floral differentiation progressed rapidly into July. The staminate buds were more advanced on a given day than the pistillate buds.
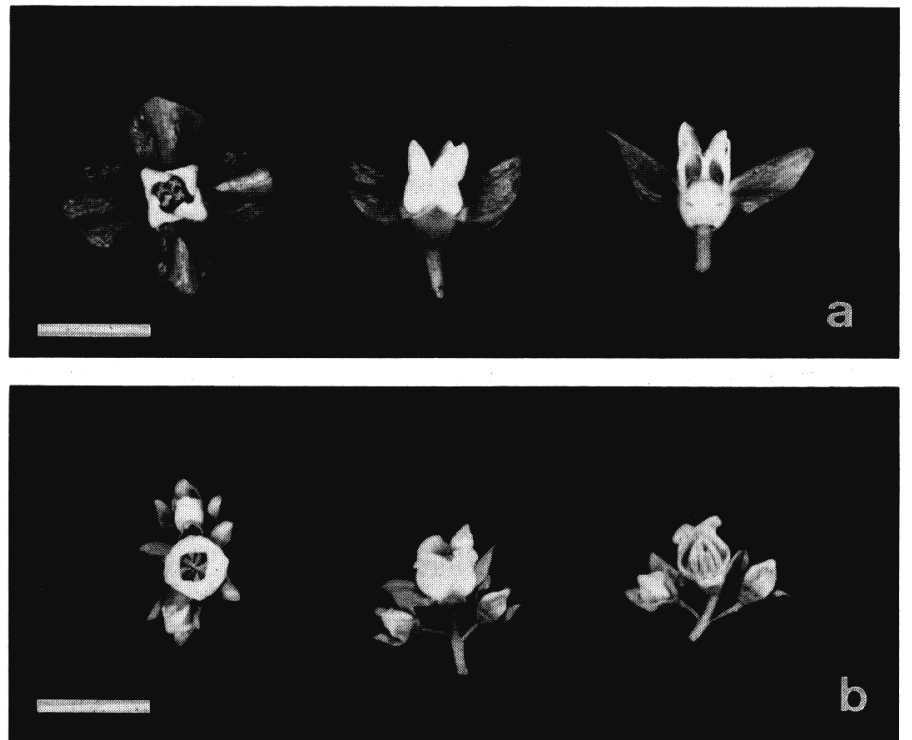

Fig. 1. Pistillate (a) and staminate (b) flowers of Japanese persimmon cultivar Hana-gosho. Scale bar $=2 \mathrm{~cm}$.
Differentiation of floral parts ceased at the end of July, the buds entering a quiescent state. The development of the mixed buds of 'Kakiyama-gaki' followed a pattern similar to that of 'Hanagosho' except that the staminate buds outnumbered the pistillate buds in this cultivar (Fig.5).

\section{Pattern of sex expression on shoots}

Shoots of 'Hana-gosho' and 'Kakiyama-gaki' that produced pistillate flowers differentiated more female buds and fewer male buds than shoots that had produced staminate flowers (Table 1). Similarly, shoots that had produced staminate flowers produced more male buds and less female buds than those that had produced pistillate flowers. Moreover, with 'Hana-gosho', the terminal buds produced the highest percentage of pistillate flowers, and the percentage of lateral buds possessing staminate flowers increased as the node distance from the apex increased. But, on the shoots of 'Kakiyama-gaki', the percentage of staminate flowers differentiating was not significantly affected by bud position.

\section{Discussion}

There are several reports concerning the time and process of flower differentiation of pistillate-type persimmons (Fukuda, 1955; Horiguchi, 1959; Nishida and Ikeda, 1961; Sobajima, 1979). According to these reports, floral initiation occurs from June to July in Japan. The floral organogenesis is only partially completed,
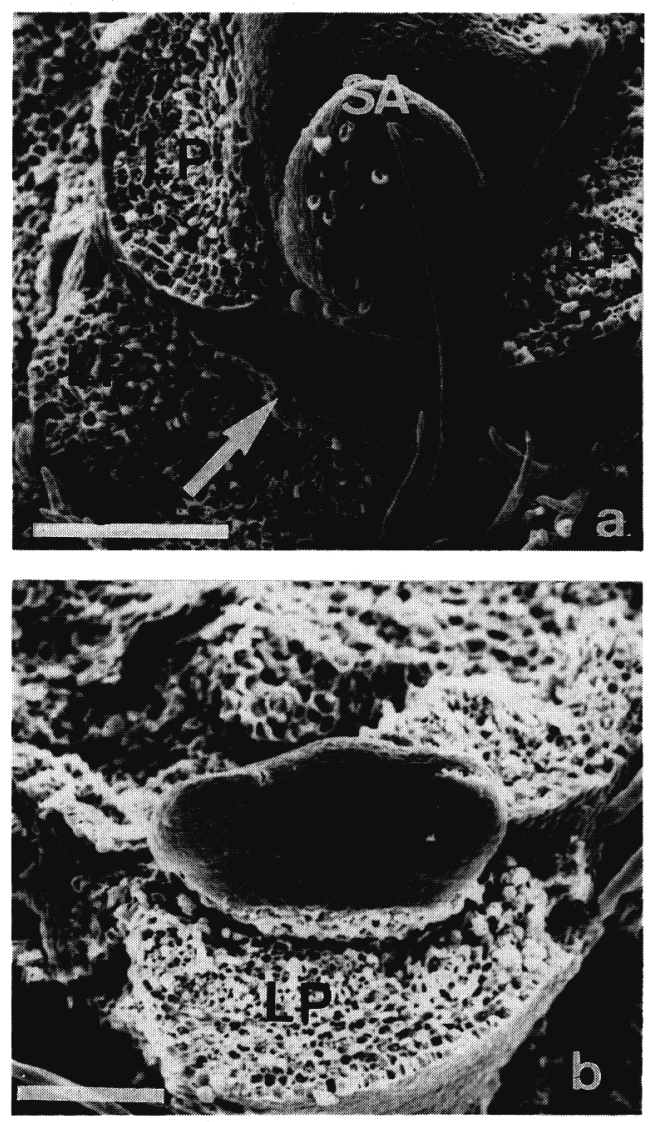

Fig. 2. Formation of a lateral meristematic apex in the axil of a leaf primordium of a mixed bud. (a) Appearance of an undifferentiated meristematic apex (arrow) in the axil of a leaf primordium (LP). The leaf primordium was removed to disclose the lateral apex and shoot apex (SA). (b) An undifferentiated apex just before shifting to a reproductive one. Scale bar $=100 \mu \mathrm{m}$. 

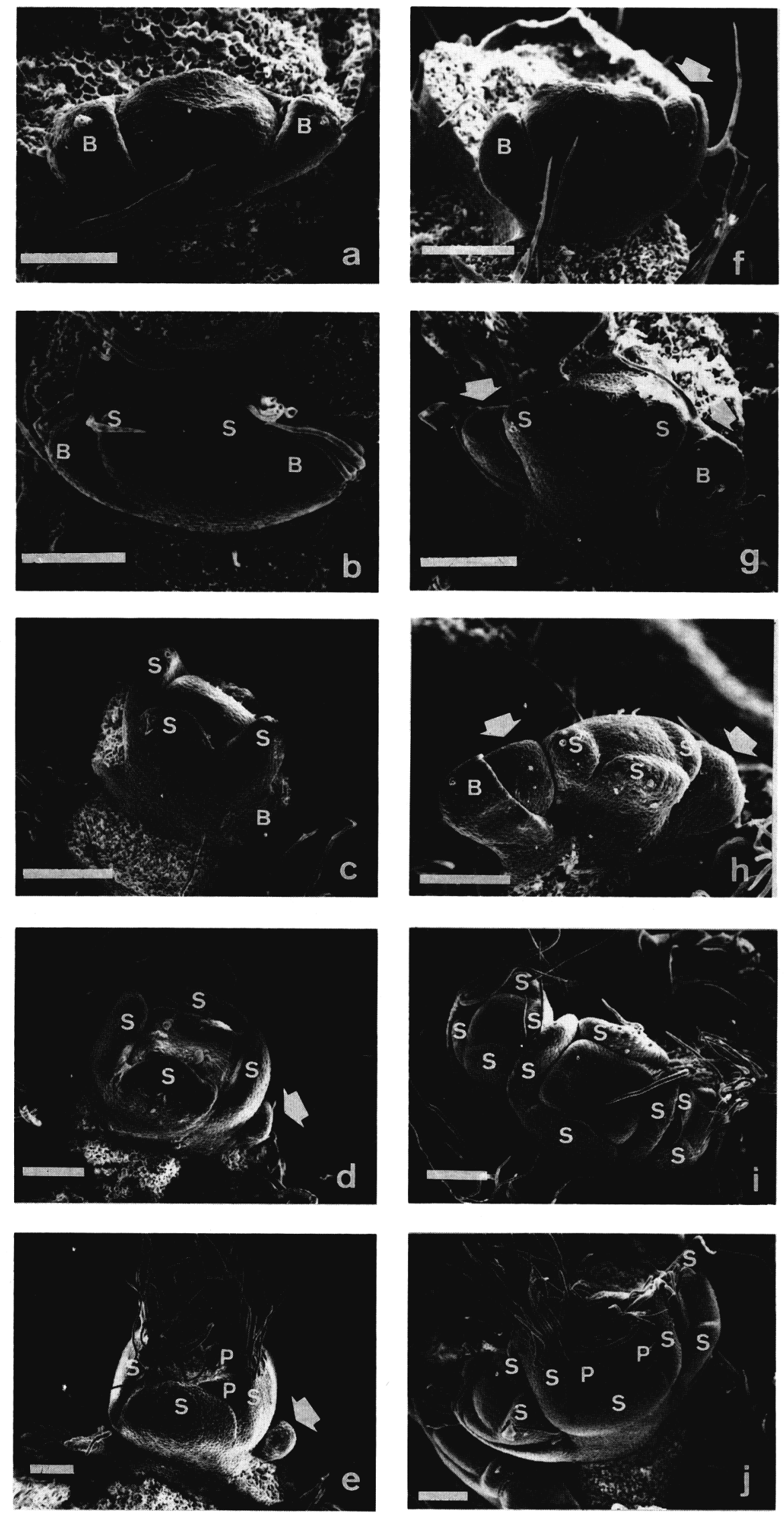

Fig. 3. Developmental stages of pistillate (a-e) and staminate (f-j) flowers primordia of Japanese persimmon cultivar Hana-gosho. Stage 1 (a and f), apical dome flattening; stage 2 (b and g), differentiation of the first and second sepal primordia; stage 3 (c and $\mathbf{~ h}$ ), differentiation of the third and fourth sepal primordia; stage 4 (d and i), swelling of petal primordia; stage 5 ( $\mathbf{e}$ and $\mathbf{j}$ ), differentiation of the four petal primordia. Arrows (f, $\mathbf{g}$, and $\mathbf{h}$ ) point to a lateral apex appearing basally to the terminal flower primordium of the cyme. The arrows (d and e) point to an undifferentiated meristematic apex. $\mathrm{B}=$ bract, $\mathrm{S}=$ sepal, and $\mathrm{P}=$ petal. $\mathrm{Scale}$ bar $=100 \mu \mathrm{m}$. 

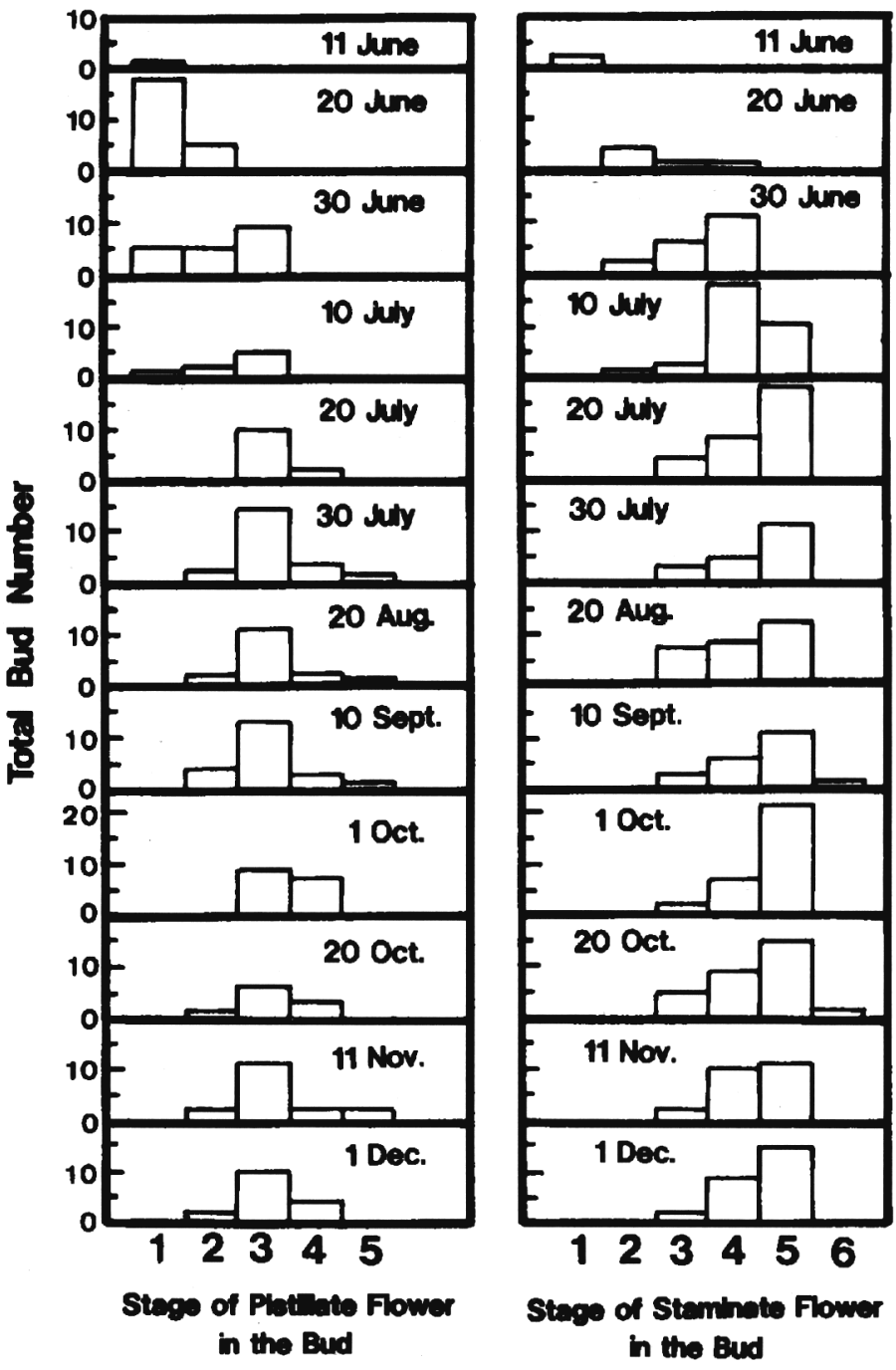

Fig. 4. Distribution of developing pistillate (left) and staminate (right) 'Hana-gosho' flower buds on selected sampling dates by stages during their ontogeny. Staminate flowers in stage 6 were a little more advanced than those in Fig. $2 \mathrm{j}$, in which the stamen primordia are swelling.

usually bract and sepal primordia and, at best, some signs of petal primordia are visible before entering dormancy. Floral differentiation proceeds rapidly after budbreak in spring (Sobajima et al., 1974).

Nishida and Ikeda (1961) and Harada (1985) reported that staminate flowers in 'Zenji-maru' and other monoecious-types could be distinguished from pistillate flowers at early stages of flower primordia initiation. They observed the presence of two lateral flower primordia basal to the terminal flower primordium in the cyme, thus establishing the time of staminate flower initiation. In contrast, Ishida et al. (1978a, 1978b) reported that the primordia of staminate flowers in 'Zenji-maru' could not be distinguished from those of pistillate flowers until March, just before budbreak. Their contention is based on the appearance of small lateral flower primordia basipetal to the terminal primordia during the quiescent period in both flower types. They also cited the presence of lateral, undeveloped meristematic apices in the pistillate-type cultivar Fuyu.

In this study, we observed two distinguishable types of floral ontogeny by July in 'Hana-gosho' and 'Kakiyama-gaki'. In one type of floral ontogeny, only one floral apex appeared, and the sepal and petal primordia were differentiated on it.
In the other, terminal and two lateral floral apices were formed, and the two lateral apices differentiated the sepal primordia concurrent with the appearance of sepal and petal primordia on the terminal apex. This type formed a cymose structure. Thus, the distinction between pistillate and staminate flowers was evident during July in 'Hana-gosho' and 'Kakiyama-gaki', supporting the reports by Nishida and Ikeda (1961) and Harada (1985). As mentioned by Ishida et al. (1978a, 1978b), we also observed a small lateral apex at the base of the developing pistillate flower primordium. However, it differed clearly from lateral apices of staminate flower in remaining undifferentiated. In the pistillate flower the lateral apices are in fact induced floral apices, but those in organogenesis are not completed due to competition with the central apex. An apex destined to become a pistillate flower would have a stronger dominance over lateral apices during organogenesis. Affluent nutrient status might induce differentiation of pistillate flowers. Actually, with monoecious-type persimmons, the nutrient status in the shoot is believed to affect sex expression, i.e., weak shoots tend to produce staminate flowers, whereas vigorous ones produce pistillate flowers (Nishida and Ikeda, 1961; Yoneyama and Wakisaka, 1957).

Furthermore, we established the regularity in sex expression by these monoecious-type persimmon cultivars. That is, the flower type on current shoots is strongly related to the determination of the flower type being initiated within the buds on the same shoot. In 'Hana-gosho', the bud position on the shoot was related to sex expression (Table 1). These corollary effects were confirmed by field observations (Yonemori et al., 1992). Shoots of 'Hanagosho' that bore pistillate flowers one season produced pistillate flowers at higher rates than staminate flowers in the following season. Shoots bearing staminate flowers behaved similarly, producing a higher percentage of buds with staminate flowers than with pistillate flowers. Also, terminal buds of 'Hana-gosho' shoots produced pistillate flowers at the highest rate in the following season, and the rates of lateral buds possessing pistillate flowers decreased as the node distance from the apex increased. These
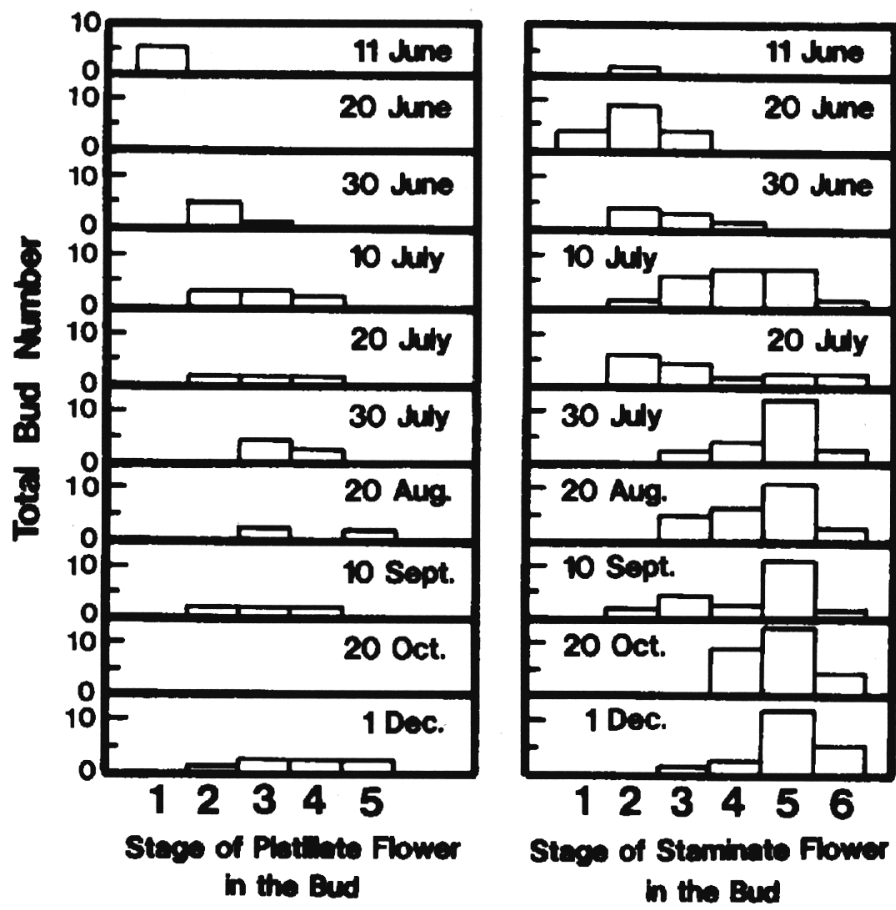

Fig. 5. Distribution of developing pistillate (left) and staminate (right) 'Kakiyamagaki' flower buds on selected sampling dates by their stages of ontogeny. 
Table 1. Sex differentiation in mixed buds of 'Hana-gosho' and 'Kakiyama-gaki' persimmon at several positions on current season's shoots bearing pistillate or staminate flowers.'

\begin{tabular}{|c|c|c|c|c|c|}
\hline \multirow[b]{2}{*}{$\begin{array}{l}\text { Flower type of } \\
\text { current-year shoot }\end{array}$} & \multirow[b]{2}{*}{$\begin{array}{l}\text { Bud position } \\
\text { on the shoot }\end{array}$} & \multicolumn{2}{|c|}{ 'Hana-gosho' } & \multicolumn{2}{|c|}{ 'Kakiyama-gaki' } \\
\hline & & $\begin{array}{r}\text { Pistillate } \\
\text { bud }(\%)\end{array}$ & $\begin{array}{c}\text { Staminate } \\
\text { bud }(\%)\end{array}$ & $\begin{array}{l}\text { Pistillate } \\
\text { bud }(\%)\end{array}$ & $\begin{array}{c}\text { Staminate } \\
\text { bud }(\%)\end{array}$ \\
\hline \multirow[t]{4}{*}{ Pistillate } & 1st (terminal) & $90.0 \mathrm{a}^{\mathrm{y}}$ & $4.0 \mathrm{e}^{\mathrm{y}}$ & $52.4 \mathrm{a}^{\mathrm{x}}$ & $42.9 \mathrm{c}^{\mathrm{x}}$ \\
\hline & $2 \mathrm{nd}$ & $56.0 \mathrm{~b}$ & $40.0 \mathrm{~cd}$ & $33.3 \mathrm{ab}$ & $61.9 \mathrm{c}$ \\
\hline & $3 \mathrm{rd}$ & $46.0 \mathrm{~b}$ & $50.0 \mathrm{~cd}$ & $23.8 \mathrm{ac}$ & $66.7 \mathrm{bc}$ \\
\hline & 4 th & $26.0 \mathrm{c}$ & $62.0 \mathrm{bc}$ & $19.0 \mathrm{bc}$ & $66.7 \mathrm{c}$ \\
\hline \multirow[t]{4}{*}{ Staminate } & 1st (terminal) & $60.0 \mathrm{~b}$ & $34.0 \mathrm{~d}$ & $0.0 \mathrm{c}$ & $100.0 \mathrm{a}$ \\
\hline & $2 \mathrm{nd}$ & $20.0 \mathrm{c}$ & $78.0 \mathrm{~b}$ & $0.0 \mathrm{c}$ & $95.2 \mathrm{a}$ \\
\hline & $3 \mathrm{rd}$ & $0.0 \mathrm{~d}$ & $96.0 \mathrm{a}$ & $0.0 \mathrm{c}$ & $90.5 \mathrm{ab}$ \\
\hline & 4 th & $0.0 \mathrm{~d}$ & $94.0 \mathrm{a}$ & $0.0 \mathrm{c}$ & $95.2 \mathrm{a}$ \\
\hline
\end{tabular}

${ }^{\bar{z}}$ Mean separation within columns at $P=0.05$ according to two-sample $t$ test.

${ }^{\mathrm{y}}$ Each value is the mean of 10 replications.

${ }^{x}$ Each value is the mean of seven replications.

regularities in sex expression of 'Hana-gosho' would confirm the involvement of apical dominance in producing female flowers, as well as the association with the previous history of the current season's shoots in sex differentiation.

\section{Literature Cited}

Fukuda, H. 1955. Effects of defoliation on the flower bud formation, and its development of Japanese persimmons (in Japanese). Studies from Inst. Hort. Kyoto Univ. 7:32-37.

Harada, H. 1985. Studies on flower initiation and bud dormancy in annual growth cycle of Japanese persimmon (in Japanese with English summary). Tech. Bul., Dept. Hort., Faculty Agr., Shizuoka Univ. 9:1-66.

Horiguchi, T. 1959. Flower bud differentiation and growing managements in kaki (in Japanese). Agr. Hort. 34: 1828-1832.

Hume, H.H. 1913. The flowers of Diospyros kaki. Trans. St. Louis Acad. Sci. 22:125-135.

Ishida, M., H. Genma, and Y. Sobajima. 1978a. Studies on the development of flower bud in Japanese persimmons. II. Morphology of winter bud (in Japanese). Abstr. Jpn. Soc. Hort. Sci. Autumn Meeting 1978:2-3.

Ishida, M., H. Genma, and Y. Sobajima. 1978b. Studies on the development of flower bud in Japanese persimmons. III. Floral differentiation in early spring (in Japanese). Abstr. Jpn. Soc. Hort. Sci. Autumn Meeting 1978:4-5.

Kajiura, I. and A. Blumenfeld. 1989. Diospyros kaki, p. 298-306. In: A.H. Halevy (ed.). CRC handbook of flowering. vol. VI. CRC Press, Boca Raton, Fla.

Nishida, T. and I. Ikeda. 1961. Flower-bud formation and development in the Japanese persimmon (in Japanese with English summary). TokaiKinki Agr. Expt. Sta. Hort. Div. Bul. 6:15-32.

Sobajima, Y. 1979. Flower bud formation and fruit growth of Japanese persimmons (in Japanese). Studies from Inst. Hort. Kyoto Univ. 9:157169.

Sobajima, Y., M. Ishida, A. Inaba, and K. Miyawaki. 1974. Studies on the development of floral organ in Japanese persimmon (cv. Hiratanenashi) after sprouting (in Japanese with English summary). Sci. Rep. Kyoto Pref. Univ., Agr. 26: 15-20.

Yonemori, K. and J. Matsushima. 1987. Morphological characteristics of tannin cells in Japanese persimmon fruit. J. Amer. Soc. Hort. Sci. 112:812-817.

Yonemori, K., K. Kameda, and A. Sugiura. 1992. Characteristics of sex expression in monoecious persimmons (in Japanese with English summary). J. Jpn. Soc. Hort. Sci. 61:303-310.

Yoneyama, K. and I. Wakisaka. 1957. Reserve nutrient and flower bud development in kaki tree (in Japanese). Agr. Hort. 32:59-60. 